\title{
Strategies and Procedures Used in Translating Ideological Islamic-Related Texts from English into Arabic
}

\author{
Bader S. Dweik $^{1} \&$ Hiyam M. Khaleel ${ }^{2}$ \\ ${ }^{1}$ Department of English, Al-Ahliyya Amman University, Jordan \\ 2 Department of English, Ministry of Education, Iraq \\ Correspondence: Prof. Bader S. Dweik, Department of English, Al-Ahliyya Amman University, Amman, Jordan, \\ E-mail:drdweik@yahoo.com
}

Received: January 25, $2017 \quad$ Accepted: February 13, $2017 \quad$ Online Published: March 1, 2017
doi:10.5539/ijel.v7n3p161
URL: http://doi.org/10.5539/ijel.v7n3p161

\begin{abstract}
This study aims to identify the various strategies and procedures that translators use in rendering ideological Islamic-related texts from English into Arabic. To achieve this purpose, the researchers have designed a translation test consisting of 10 extracts with ideological content written by Muslim and non-Muslim writers. The researchers have selected a purposive sample of 20 translators to perform the test. Only 16 of them have responded. The results of the test have been analyzed qualitatively and quantitively. The study reveals that two strategies have been used by the translators: foreignizing and domesticating. It also reveals that 12 procedures have been employed by the translators: recognized translation, literal translation, naturalization and paraphrasing procedures underlying the foreignizing strategy and transposition, equivalence, omission, addition, glossing, magnifying, moderating and the label procedures underlying the domesticating strategy.
\end{abstract}

Keywords: ideology, translation, islamic-related texts, strategies, procedures

\section{Introduction}

Each community has its own ideas, beliefs, and norms which constitute its ideology and differentiate it from other communities. History, traditions, politics, language and religion play vital role in producing different ideologies. In the course of inter-cultural interaction, cultural and ideological differences are supposed to be tolerated, understood and accepted. Yet throughout history, ideologies have been employed in different kinds of conflicts which may take the form of intellectual, spoken or even military conflict.

The most sensitive area of ideological conflict is religion. Religious ideologies are used in the current conflict in the Islamic world. New Islamic-related terms are coined by Muslim and non-Muslim ideologists. These terms are often used in mass media, political and religious discourses to serve certain agendas. They often carry connotative meanings. Translation as a means of communication mediates in this ideological conflict. Translators play an important role in rendering ideological Islamic-related texts. They may find themselves in a critical situation in which they have to be faithful to a source text that opposes their own ideology and the ideology of their readership. They may get involved in ideological interference when rendering such texts. The strategies and procedures which are chosen by translators would characterize their translation as ideological or not. The translator's ideological assumptions and those of his/her target audience will play an important role in interpreting the Source Text (ST) and the strategies he/she uses in rewriting it (Lefevere, 1992). Among the different procedures or techniques which are used in translation, there is no single typical procedure to be adopted. The translator has to decide which procedure to use according to contexts, intention, and ideology. Using a certain procedure rather than the other may reflect a kind of manipulation on the part of the translator. For instance, transferring (borrowing) the term "Mohammedism" to the Target Text (TT) or using the cultural equivalent "Islam" reflects different ideological attitudes since they carry different connotative meanings.

Recently, transmission of ideology through translation has become a matter of question to both theorists and translators. Ideological shift in translation may lead to a shift in consensus view. Translating ideological Islamic-related texts is so sensitive that the translator should be careful in rendering such texts. The strategies and procedures that are used by the translator would lead to disparity in translation and reflect different ideological views. This is why the researchers intend to conduct this research. This study aims to identify the 
various strategies and procedures that translators use in rendering ideological Islamic-related texts from English into Arabic. The study intends to answer the following question:

What strategies and procedures are used by translators in rendering ideological Islamic-related texts from English into Arabic?

\section{Review of Literature}

There are several scholars and theorists who have written on the impact of one's ideological world view on one's translation. The translator's ideology is reflected in his/her interpretation of a text and his/her translation. Ideology can be seen from different perspectives. Eagleton (1991, p. 1) defines it as "a text woven of a whole tissue of different conceptual strands". He also refers randomly to some definitions of ideology such as (a) identity thinking, (b) the conjuncture of discourse and power, and (c) action-oriented sets of beliefs.

Simpson (1993) views ideology, from a critical linguistic angle, as" assumptions beliefs and value-system which are shared collectively by social groups" (p. 5). This definition suggests that ideology is the vital element of any social group. He states that the dominance of a certain ideology stems from the powerful and authoritative political, religious and social institutions which circulate their ideologies by using specific linguistic practices. He indicates that "language reproduces ideology" (p. 6) is an essential element of critical linguistic principles. So language expresses ideologies and constitutes them.

Hatim \& Mason (1997) state that ideologies may be manifested in individuals as well as groups of individuals. They define ideology as "a body of assumptions which reflects the beliefs and interests of an individual, a group of individuals, social institution...etc., and which ultimately finds expression in language" (p. 218). The definition also emphasizes the interconnection of ideology and language.

Van Dijk (2001, p. 12) defines ideology as "a special form of social cognition shared by social groups". He proposes three models which have a crucial effect on discourse and social practices. These are:

social models represented in ideologies, knowledge, and attitudes of the social group,

mental models which are represented in " episodic memory" i.e. people's own experiences, and

context models which are represented in people's perception or interpretation of the current situation or activity they take part in.

These three models may be "ideologically biased models" and they may "form the input of discourse production, and may thus give rise to biased topics, lexical items, or metaphors, among many other (especially semantic) properties of discourse" (Van Dijk, 2001, p. 17).

Newmark (1981) states that the choice between communicative and semantic methods is relatively decided by the attitude towards mass readership and the text producer. The choice is implicitly seen as ideological mediation. He emphasizes that " $[t]$ he particular prejudicial and prejudiced cultural senses of some words have to be noted by translators" (p. 118). He also highlights the peculiarity of words that convey or suggest connotative meanings apart from their explicit names. He indicates that "such words are based on the feelings and moral ideas they arouse in both the transmitter and receptor" (p. 119). Moreover, Newmark draws the attention to "evaluative language" which denotes the author's assessment of values explicitly or implicitly. He states that some words such as "terrible, passable" have unsettled meaning unless they are based on "a scale" which copes with writers value judgments and then might be transformed according to the target culture. Words such as revolutionary, formalists...etc gain their evaluative fact from the culture they derived from. In translating such words, Newmark states that the translator may support the reader with a footnote to sustain the "thought content" of the Source Text (ST). Furthermore, the translator is authorized to assess the subjectivity of the writer's evaluations. He also indicates that while some verbs are informative, others may denote positive or negative meaning which should be taken in account in translation.

Newmark (1988) indicates that it is misleading to translate concept—words such as "radicalism" or "realism" literally because they locally have different connotations. He proposes the following procedures to be used in translation:

1). Naturalization: to adapt the SL word to the normal pronunciation and morphology of the Target Language (TL).

2). Transposition that is to make a shift in grammar from the Source Language (SL) to TL.

3). Cultural equivalent: that is to replace SL cultural word with its equivalent in the TL.

4). Thorough-translation: that is to translate common collocation names of organizations literally. 
5). Recognized translation: that is to render institutional terms by using its official or accepted translation. The translator can gloss it if he/she wants to show his/her disagreement with the official rendering.

6). Paraphrasing is to add an explanation of the meaning when the SL text has important implications and omissions.

7). Notes, additions, glosses: that is to add extra information to clarify some cultural, technical and linguistic words or to express his/her opposition to the original text.

8). Labeling: a tentative translation, marked by inverted commas. It is often used with new institutional terms.

Venuti (1995) presents two strategies of domestication and foreignization. He indicates that using a certain strategy in a certain socio-cultural situation may reflect "ideological implications". Domestication strategy is used by the translator to serve his/her target audience so he/she makes certain changes in the ST so as to cope with the values and conventions of the target-language culture. This strategy implies the ST has to submit to transformation to make the TT "transparent, fluent and natural". Foreignization is the second strategy that Venuti (1995) presents. This strategy aims to maintain the foreign text without changes. The translator retains cultural and linguistic elements of the ST in order to create the same effect of the ST on its original readership. The TT will be somehow difficult to understand since it is replete with foreign culture and it might also violate the values and beliefs of the target culture (Nazzal, 2012).

Al-Thuwaini (2006) explored the role ideology plays in changing the denotative meaning of a term when used in sensitive texts, such as religious or semi-religious texts. It also aimed to propose a way by which a cultural equivalence can be used in such cases. The researcher translated a chapter from Lewis's book The Crisis of Islam into Arabic and analyzed it. He pointed out that The Crisis of Islam (2003) is oriented to western readers to help them understand why Muslim world prefers to return to a "sacred past" and dogmatically rejects "modernity". To draw the attention to the author's argument, the researcher adopted foreignization strategy (Venuti, 1995, 1998) and descriptive strategy (Hatim, 2001). The study showed that translation of sensitive texts (religious and political) demands the approach of all-fold concept of ideology since equivalence alone is not enough to render the connotative meaning and the effect of the source text; the translator, according to historical review, suggested some Arabic equivalents for critical terms which are widely used in the world media such as Islamism, fundamentalism, and jihad. These equivalents may provide accuracy and formulate the questionable agreement on a final ideologically translatable concept and the thesis call to stabilize a project for a "standardized" translation to such controversial religious terms which reflect the history of Muslims, their identity and their criterion of fidelity and unity.

Keshavarz \& Zonoozi (2011) investigated the manipulation of Ideology in a translation of political texts. The study aimed to find out whether the ideological reforms of political texts modified in the process of translation or not and to find out whether certain lexical patterns, a grammatical structure used in translation underlying certain Ideology. To achieve these goals the researchers chose three English books as well as their translation in Persian to be analyzed according to Critical Discourse analysis (CDA) approach. The study revealed that translators used certain grammatical structures and semantic discursive strategies as an ideological device. The basic strategy used by the Persian translators was of positive self-presentation and negative-other presentation, and the analysis of macro-features disclosed the translator's ideological inclinations and judgments towards the source texts and their authors.

Al-Harahsheh (2013) investigated the effect of the translators' ideology on rendering Islamic texts written by non-Muslim and translated by Muslim students. For this purpose, three Islamic texts written by non-Muslim were selected to be translated by 49 undergraduate students ( 48 Muslim students and one Christian student). The students were not informed of the exact aim of the study to avoid interference in their translation. The researcher employed CDA to explore the investment of ideology in translating religious texts. The study revealed that ideology has a significant impact on the translation of Muslim students when rendering Islamic texts written by non-Muslims; they were predisposed to add honorific expression after the name of prophets and names of sacred places; they omitted and replaced words that imply negative connotations to lessen their impacts so as to cope the TT with their religious and cultural ideology; and the study indicates that CDA is an important tool in investigating the social, cultural and ideological practices in translation.

AShubbak (2013) investigated the impact of ideology on translating news items among Arab translators. The purpose of the study was to investigate how Arab translators render sensitive news items from English into Arabic. It also aimed to discover the influence of the translators' affiliation on the translation. Moreover, the study aimed to show how inexperienced Arab translators translate controversial news items in comparison with translators of different news agencies. To achieve these purposes, the researcher examined news reports rendered 
from English into Arabic in five news agencies and daily newspapers that were the: BBC, AFP, Reuters, France 24, and Alrai Jordanian Daily Newspaper. The analysis focused on features that indicated the utilized strategies in translation, such as deletion, addition, semantic change, structure shift, and distortion. Moreover, a twenty-five item test was conducted to graduate students enrolled in translation the English language programs at two Jordanian universities to explore the impact of ideology on translating news items among novice translators. The study revealed that Arab translators used addition, omission, mediation (semantic change) and dynamic equivalence as manipulative strategies when they render controversial news items; using manipulative strategies varied between experienced and inexperienced translators due to the policy of the news agencies; and novice translators' translation decidedly affected by their political and cultural affiliations. Their ideological intervention was consciously used and not for lack of knowledge or incompetency.

Alghamdi (2014) investigated the notion of ideology transference through the translated texts. The study aimed to explore the effect of the social-cultural and ideological restraints on the translator's strategies used in translation. It also aimed to identify the ideological presumption implied in both the ST and TT. To achieve this purpose, the researcher selected two different Arabic translated version of Chomsky's book "Media Control". The data analysis was based on CDA. The three texts were examined at two levels: Macro-level analysis to investigate when, how, where and what the text is and Micro-level analysis to investigate: lexicalization which inspects the use of biased words and ideologically hidden terms and dominate syntactic choices which inspect the deviation among verbs, adjectives, pronouns, proper noun and adverbs in both TTs. It also investigated the important differences in terms of modalisation, nominalization, passivization and addition versus omission in translation and foreignization versus domestication. The study revealed that there were cogent differences between the two TTs in choosing the lexical items and other syntactic structure in comparison with the ST; the cogent difference denoted some ideological transference through translation process; and to a degree, these differences were also affected by the translator's socio-cultural and ideological restrains.

\section{Methodology}

The researchers developed a test to investigate the various strategies and procedures that translators used in rendering ideological Islamic-related texts from English into Arabic. The test embodied two parts. While the first comprised the demographic data of the participants, the second was dedicated to translating 10 extracts derived from books, articles and websites (written by Muslim or non-Muslim writers). Three of them were non-Muslim orientalists, known for their controversial and influential writings about Islam, namely George Sale, Bernared Lewis, and Daniel Pipes. The three Muslim ideologists whose ideas about Islam were influential and controversial for both Muslims and non-Muslims, were Abu Alaa Maududi, Sayyed Qutb, \& Ali Sharia'ti. The two other writers were Muslim American scholars and writers, namely Imam Zaid Shakir (a specialist in Islamic spirituality) and Laila Ahmed (a specialist in Islam and Islamic feminism). To help the translators figure out the ideology in each extract, the researchers provided the names of the writers of each one. Newmark's (1981) evaluative language is considered in designing the test which contains: controversial terms, vague adjectives, and verbs with negative connotations which might result in disparity in translation due to the ideologies of the translators (See Appendix A). After preparing the test, it was given to a panel of four university professors who have a teaching experience in translation and linguistics to assure the validity of the test. They were asked to comment on the suitability of the extracts and to suggest any modifications if needed to achieve the objectives of the study. Their feedback provided helpful and valuable comments. They acknowledged that the texts were difficult and their translation required time and deep understanding. The reliability of the test was examined by means of a test-retest. The translation pretest was administered to a group of five professional translators who were not included in the sample but had the same characteristics. The test was repeated after one week. The results were stable.

The sample of the study embodied professional translators in Jordan. Out of 20 translators who were chosen purposively to perform the test, only 16 translators responded to the designed test. The demographic data of the participating translators and their general background included gender, age, nationality, work experience, educational background and the major in college or university. The sample included 8 males and 8 females whose ages ranged between 23 and more than 40 years. All of them were Jordanians except one Iraqi translator. Their work experience ranged from one to more than 40 years in translation. All of them were Muslims; twelve of them held M.A degrees, two were holders of Ph.D., and two were B.A holders. Most of them majored in English, literature, linguistics, and translation. However one of them majored in English for specific purposes and another one majored in Islamic theology.

The data, which were collected from the test, were analyzed according to Newmark's (1988) procedures of translation, then classified under two strategies: foreignization and domestication which were presented by 
Venuti (1995) to point out two kinds of ideologies in translation. Furthermore, the data were also analyzed in the light of the review of related literature, especially those which were related to the procedures used by the translators to utilize ideology such as omission, addition, magnifying and moderating. Three alternatives were used in analyzing the test:

1). Procedures such as recognized translation, naturalization (without glossing), literal translation and paraphrasing were classified under foreignizing strategy.

2). Procedures such as transposition, equivalence, addition, omission, magnifying, moderating, glossing and labeling which may suggest utilizing ideologies were classified under domesticating strategy.

3). The wrong translations which distorted the meaning due to the referential and linguistic mistake were identified. Furthermore, the percentages and frequencies of the responses were estimated.

\section{Results}

The results show that the translators have used two strategies, the foreignizing strategy, accounting for 191 frequencies $(56.85 \%)$ of the total responses and the domesticating strategy accounting for 123 frequencies (36.60\%) of the total responses (See Appendix B). Meanwhile 22 frequencies (6.55\%) of the total responses have been wrong answers. In foreignizing strategy, the translators have employed four procedures; recognized translation (133) frequencies, literal translation (43), naturalization (12) and paraphrasing (3). In domesticating strategy, eight procedures have been employed by the translators: transposition (40), equivalence (39), omission (21), addition (11), magnifying (4), glossing (4), moderating (3), and label (1).

The procedures which were used in the foreignizing Strategy:

1). Recognized translation

It stands as the most prominent procedure, accounting for 133 frequencies $(39.58 \%)$ of the total responses. It underlies the tendency to foreignize the TT by employing a generally accepted translation to convey the message

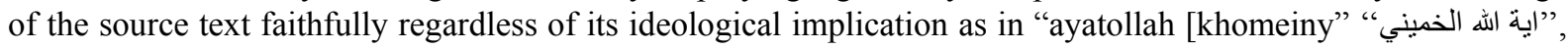

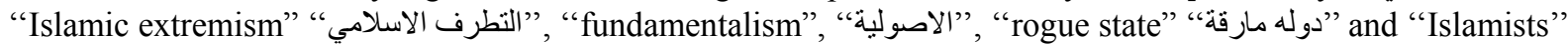
“"...etc.

\section{2). Literal translation}

It stands as the second procedure, accounting for 43 frequencies $(12.80 \%)$ of the total responses. It depends on the literal meaning provided by dictionaries in rendering the ST regardless of the ideological, political or cultural connotation. Using this procedure can be attributed to two factors: first:- inability to figure out the contextual meaning either because of its ambiguity as in translating " preemptive" to "الاستباقية"، "الوقائية " or being conflated as in rendering "fundamentalism" into "التعصب", Second: lack of knowledge as in rendering "Islamist

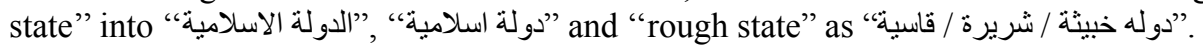

\section{3). Naturalization}

In this procedure, the translator transfers a word from SL to TL with phonological and morphological modifications. It stands as the third procedure used in the foreignizing strategy, accounting for 12 frequencies (3.57\%) of the total responses. Although it adapts the normal pronunciation and morphology of the TL, it sustains the ideological or political implications of the ST. By rendering "Mohammedism" into "الححمدية", translators sustained the ideological implication of the term. Naturalization was also used in rendering "radicalism" into "الراديكالية" which does not provide the connotative meaning of the term. It was left to the reader to figure out the ideological and political connotation of the terms.

4). The paraphrase translation

It is the least used procedure by the translators who used foreignizing strategy in rendering the texts. It accounts for 3 frequencies $(0.90 \%)$ of the total responses. In this procedure, translators have substituted some terms to give an explanation of the meaning without changing the connotative meaning as in translating "Mohammedism" into "دين محمد" which maintains the ideological meaning of the ST. The term "rouge state" is also rendered into "دولة تفتقر الى اسس الحكم", lietrally "a state that lacks the basis of the ruling”.

The procedures which were used in the domesticating strategy:

1). Transposition

It is the most prominent procedure employed by translators in the domesticating strategy, accounting for 40 frequencies $(11.90 \%)$ of the total responses. This procedure involves a shift in grammar from SL to TL. The change in grammar might be indicative of ideological mediation. This procedure was used heavily by the 
translators in rendering item (2.a, c) changing singular into plural. Rendering "recruit an assassin" into "تجنيدالقتله " and "standard Islamic practice" into " which may be indicative of generalization. It was also used in rendering item (3.a). "Islamic extremism current in the present time" was translated by employing

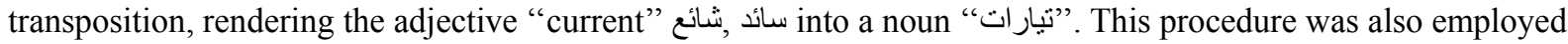
in item (4.a) by rendering "An Islamist state" into "الدولة الاسلامية" changing it from indefinite to definite.

2). Equivalence

It is the second procedure used in domesticating the TT, accounting for 39 frequencies $(11.60 \%)$ of the total responses. Although it seems reasonable to use the cultural equivalence in rendering texts related to Islam, yet sometimes this procedure failed to transmit the ideological or political connotation of some terms unless they are supported by a gloss. The term "Mohammedism" was translated by $(12.50 \%)$ of the translators to its cultural equivalent " which deprives the reader of realizing the author's ideology that underlies the use of the term "Mohammedism". "A rogue state" was translated by (12.50\%) of the translators as " دولة خوارج" or "مولة حرابة" which also deprives the reader of realizing the political connotation of the term. "To veil" was translated by (87.50\%) of the translators as " which does not solve the problem of polysemous word "veil" or "hijab".

\section{3). Omission}

Although deleting a word or some words from the ST while translating is considered misunderstanding of the author, yet omission was employed in domesticating the TT, accounting for 21 frequencies $(6.25 \%)$ of the total responses. The use of this procedure can be attributed to two factors: First, the inability of translators to render some ambiguous words, Second the translator's intention to omit words that are opposite to his/her beliefs or the beliefs of his/her readership. The honorific title "ayatollah" was omitted by $(12.50 \%)$ of the translators while translating Item (2.b). The procedure was also used in Item (3.b, c, d \& e), "radicalism" was omitted by (18.75\%), "preemptive" was omitted by (25\%), "fundamentalism" was omitted by (25\%) and "hierarchy" by $(31.25 \%)$ of the translators. It was also employed by (12.5\%) of the translators in rendering Item (5) by omitting the second part of the sentence "by the revelation given to our prophet Muhammad..." to avoid comparing the Prophet Muhammad (PBUH) to other figures. The term "Dar-ul-Islam" was also omitted by $(6.25 \%)$ of the translators.

\section{4). Addition}

Addition, accounting for 11 frequencies (3.27\%) of the total responses. It was used by (6.25\%) of the translators in rendering "Mohammedism" into "دين محمد صلى الله عليه وسلم". In Item (2.c.) it was used by (18.75\%) of the translators rendering "standard Islamic practice" into "الممارسات الاسلاميه السمحه / الدين الاسلامي الحنيف". In Item (7a.)

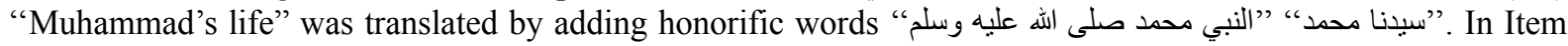
(9) "God's guidance" was translated by (12.50\%) as "توجيهات الله سبحانه وتعالى ". Addition was also used in Item (6)

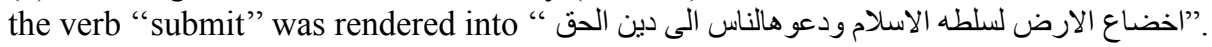

\section{5). Magnifying}

This procedure relies on the lexical choice of the translator. The meaning of the word might be exaggerated. It accounts for four frequencies (1.19\%) of the total responses. The verb "de- politicized" was rendered by (25\%)

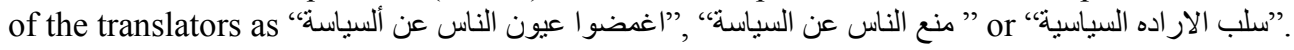

\section{6). Glossing}

This procedure provides the translator with a chance to add cultural, technical or linguistic information to his/her translation. Although it might be considered the best way to deal with ideological texts, it was used only in $(1.19 \%)$ of the total responses. The term "Mohammedism" was glossed by $(12.50 \%)$ of the translators. It was rendered into "الاسلام" or " and providing a footnote that explained the ideological offensive connotation of the term. "Rogue state" was also glossed by (6.25\%) of the translators, rendering it into "دولة مارقة" and providing a footnote to explain the political connotation of the term. In Item (8.b.) the word "Jahilyyah" was rendered into "الجاهلية" and was glossed by (6.25\%) of the translators providing a footnote to explain the meaning used by Sayyed Qutb for "Jahilyyah".

\section{7). Moderating}

This procedure relies on the lexical choice of the translator. A word with negative connotation might be mollified in the TT to lessen its effect and to be in line with the target culture. It accounted three frequencies $(0.90 \%)$ of the total responses. In item (5) "better than" was replaced by the correlative conjunction "not only... but also..." which changes the idea from comparison into parallelism. In Item (6) the word "submit" was translated by 
(12.50\%) of the translators as "تنعتنق الاسلام", to lessen the effect of the verb "submit" which denotes the negative meaning of "enforcing people to Islam".

8). Label translation

This procedure is a temporary translation, which should be made in inverted commas. It is conditional and can be later departed. It was the least used procedure. It was used only one time $(0.30 \%)$ in rendering the term "Dar-ul-Islam" into "with inverted commas which might be used to show disagreement to the term.

\section{Discussion and Conclusion}

The results show that $(56.85 \%)$ of the translators have adopted the foreignizing strategy in which they employed four procedures; recognized translation, literal translation, naturalization, and paraphrasing arranged in a descending order by their frequencies. The heavy use of recognized and literal translation reflects the translators' tendency to sustain the exact message of the ST. Although in naturalization, the translators have adapted the phonology and morphology of the target language, they retained the ideology of the ST. Paraphrasing is also used in a way that retained the message of the ST as in rendering "Mohammedism" into "دين محمد" which maintained the same connotative meaning of the term "Mohammedism". This agrees with Venuti (1995) who states that the purpose of foreignization is to maintain the cultural and linguistic elements of the ST in order to have the same effect that the original readership receive. It also agrees with Nazzal (2012) who believes that in using foreignization, the TT will be difficult to understand because it will be loaded with foreign culture and it will also be offensive to the target culture. On the other hand, $(36.60 \%)$ of the translators have adopted the domesticating strategy, i.e., they tried to communicate the message of the ST taking into account the cultural and ideological beliefs of their readership. Eight procedures have been utilized by the translators to underlie the domesticating strategy. They are transposition, equivalence, omission, addition, magnifying, glossing, moderating and label, arranged in a descending order by their frequencies. The most utilized procedure in the domesticating strategy is transposition where a shift in the structure is made to modify the message of the ST to meet the ideology of the readership. There is a shift from singular into plural which might suggest generalization. There is also a shift from indefinite to definite which suggests specification. These two examples have made a shift in ideology whether it is intended or not. This agrees with Keshavarz \& Zonoozi (2011) who believe that translators use certain grammatical structures as a device to utilize ideology. The equivalence procedure is heavily employed by the translators in the domesticating strategy. Equivalence helps to make the TT easy and readable but sometimes it fails to denote the political and ideological connotations. This agrees with Venuti (1995) who believes that domestication implies the submission of the ST to conversion to make the TT "fluent and natural". It also agrees with AL-Thuwaini (2006) who states that equivalence alone is not enough to convey the connotative meaning of some words or to create the same effect of the source text.

Omission is also used by the translators to bring the TT to the TL culture. Omitting some words can be easily attributed to ideological reasons as in omitting the second part of the sentence in (item 5) to avoid comparing the prophet (PBUH) with other figures. By omitting terms like "radicalism", "fundamentalism", "hierarchy" etc., it is difficult to decide whether it is attributed to the incompetency of the translators or to ideological reasons to make TT meet the culture and ideological values of the target readership. By adding honorific words, translators also try to meet the value of their readership. This agrees with Al-Harahsheh (2013) who states that some translators are predisposed to add honorific expressions after the name of the prophet and they omit words that denote negative connotation to lower their effect. It also agrees with Ashubbak (2013) who indicates that the Arab translators use addition, omission, equivalence when rendering controversial news items.

Magnifying and Moderating have been used by the translators to make a semantic shift. It relies on the lexical choices of the translators who either try to exaggerate (magnifying) a word or to reduce its effect (moderating) especially with words that have a pejorative meaning. These two procedures might be indicative to ideological mediation. This also agrees with Al-Harahsheh (2013) who indicates that translators of ideological and religious texts tend to replace words with negative connotations by other words to reduce their impact. It also agrees with Alghamdi (2014) who states that the translators' socio-cultural and ideological constraints result in disparity between ST and TTs in choosing the lexical items. Glossing serves as the best procedure to administer ideological texts. It enables the translator to transmit the message of the ST faithfully and communicates any ideological implications to his readership. It requires further research and efforts which might be the reason behind its little use. It only accounts for $(1.19 \%)$ of the total responses. The terms "Mohammedism", "rogue state", and "Jahilyyah" are glossed by the translators to provide their connotative meaning. This agrees with Newmark (1988) who states that glossing can be used by the translators to clarify cultural words or to show opposition or disagreement to the ST. 
Label procedure is the least used one. It accounts only for $(0.30 \%)$ of the total responses. It is a contingent translation, putting the rendered term in inverted commas to indicate that it can be departed later. Although this procedure is often used in rendering a new institutional terms, it is used here to render the revived term "Dar-ul-Islam" which is rendered to "دار ألإسلام" with inverted commas to indicate that using this term is conditional or to show disagreement with it. This procedure also provides an aid to deal with ideological texts.

In conclusion, results obtained from the test indicate that translators have used two main strategies in rendering ideological Islamic-related texts. They are the foreignizing strategy, accounting for 191 frequencies $(56.85 \%)$ of the total responses and the domesticating strategy, accounting 123 frequencies $(36.60 \%)$ of the total responses and the other 22 frequencies $(6.55 \%)$ of the total responses have been wrong answers. The interpretation also indicates that the translators have utilized the following 12 procedures in rendering ideological Islamic-related texts; recognized translation (133 data); literal procedure (43 data); transposition (40 data); equivalence (39 data); omission (21 data); naturalization (12 data); addition (11 data); glossing (4 data); magnifying (4 data); moderating (3 data); paraphrasing (3 data) and label (1 data).

The study also reveals that, on the one hand, recognized, literal, naturalization and paraphrasing procedures underlie the foreignizing strategy to sustain the ideology of the ST. On the other hand, transposition, equivalence, omission, addition, glossing, magnifying, moderating, and label procedures underlie the domesticating strategy to modify the TT so as to be in line with the target ideology.

\section{References}

Alghamdi, S. (2014). Translation and ideology: A critical discourse analysis of Chomsky's media control and its Arabic translation. International Journal of Linguistic, 6(3), 118-132. https://doi.org/10.5296/ijl.v6i3.5605

Al-Harahsheh, A. (2013). Translation of Islamic texts and ideology. Arab World English Journal (Special issues on translation), (2), 107-117.

Al-Thuwaini, M. (2006). Ideology in translating religion related discourse (Unpublished master's thesis). American University of Sharjah, Sharjah, UAE.

Ashubbak, I. (2013). The Impact of ideology on rendering news items among Arab translators (Unpublished master's thesis). Middle East University, Amman, Jordan.

Eagleton, T. (1991). Ideology: An introduction. New York: Verso.

Hatim, B. (2001). Teaching and Researching Translation. Harlow: Pearson Education Limited.

Hatim, B., \& Mason, I. (1997). The translator as communicator. London: Routledge.

Keshavarz, M., \& Zonoozi, L. (2011). Manipulation of ideology in translation of political texts: A critical discourse analysis perspective. Journal of Language and Translation, 2(1), 1-12.

Lefevere, A. (1992). Rewriting and the manipulation of the literary fame. New York: Routledge.

Nazzal, A. (2012). Translation as an intercultural communication encounter: A deconstructive approach. Arab World English Journal, 3(1), 77-102.

Newmark, P. (1981). Approaches to translation. Oxford: Pergamon Press.

Newmark, P. (1988). A Textbook of translation. London: Prentice Hall.

Simpson, P. (1993). Language ideology and point of view. London: Routledge. https://doi.org/10.4324/9780203312612

Van Dijk, T. (2001). Discourse, ideology and context. Folia Linguistica, 35(1-2), 11-40. https://doi.org/10.1515/flin.2001.35.1-2.11

Venuti, L. (1995). The translator's invisibility: A history of translation. London: Routledge. https://doi.org/10.4324/9780203360064

Venuti, L. (1998). The scandals of translation: Towards an ethics of difference. Abingdon: Taylor \& Francis US. https://doi.org/10.4324/9780203269701 


\section{Appendix A}

\section{The Test}

Translate the following:

1) "It is certainly one of the most convincing proofs that Mohammedism was no other than a human invention that is owed its progress and establishment almost entirely to the sword." (George Sale)

2) "In using a fatwa to pronounce a death sentence and recruit an assassin, the ayatollah[Khomeini] was deviating very considerably from standard Islamic practice." (Bernard Lewis)

3) "There are several forms of Islamic extremism current at the present time. The best known are the subversive radicalism of the AL-Qaida and other groups that resemble it all over the Muslim world, the preemptive fundamentalism of the Saudi establishment, and the institutionalized revolution of the ruling Iranian hierarchy. All of these are, in a sense, Islamic in origin, but some of them have deviated very far from their origins." (Bernard Lewis)

4) "An Islamist state is, almost by definition, a rogue state, not playing by any rules except those of expediency and power, a ruthless institution that causes misery at home and abroad. Islamists in power means that conflicts proliferate, society is militarized, arsenals grow, and terrorism becomes an instrument of state." (Daniel Pipes)

5) "As Muslims we may well continue in our struggles. However, those struggles would be better informed by the revolutionary teaching of Bakunin, Gorges Soret, Rosa Luxemburg, Lenin Mao, Che Guevara, and others than by the revelation given to our Prophet Muhammad, Peace and Blessings of God upon him." (Imam Zaid Shaki)

6) "Islam is a revolutionary faith that comes to destroy any government made by man. Islam doesn't look for nation to be in better condition than another nation. Islam doesn't care about the land or who own the land. The goal of Islam is to rule the entire world and submit all of mankind to the faith of Islam." (Abu Ala Maududi)

7) "During Muhammad's lifetime and only towards the end at that, his wives were the only Muslim women required to veil. After his death and following the Muslim conquest of the adjoining territories, where upper-class women veiled, the veil became a commonplace item of clothing among Muslim upper-class women, by a process of assimilation." (Leila Ahmed)

8) "Indeed, there is no Islam in a land where Islam is not dominant and where its Shariah is not established; and that place is not Dar-ul-Islam where Islam's way of life and its laws are not practiced. There is nothing beyond faith except unbelief, nothing beyond Islam except Jahilyyah, nothing beyond the truth except falsehood." (Sayyed Qutb)

9) "...there are two kinds of culture; the Islamic culture, which based on the Islamic concepts and the Jahili culture, which is...based on one thing, that is giving human thought the status of god so that its truth or falsity is not to be judged according to God's guidance." (Sayyed Qutb)

10) "During their reign, the Abbasids, who were more experienced (than the Umayyads), de-politicized the people ...that is to say, they made the people less sensitive to the issue of imamat (leadership) and the destiny of society". (Dr. Ali Sharia'ti) 


\section{Appendix B}

Frequencies and Percentages of Strategies Employed in Translating Ideological Islamic-Related Texts

\begin{tabular}{|c|c|c|c|c|c|c|c|c|c|}
\hline \multirow[t]{2}{*}{ No. } & \multirow[t]{2}{*}{ Item } & \multicolumn{2}{|c|}{ Foreignizing strategy } & \multicolumn{2}{|c|}{ Domesticating strategy } & \multicolumn{2}{|c|}{ Wrong answer } & \multicolumn{2}{|l|}{ Total } \\
\hline & & Freq & $\%$ & Freq & $\%$ & Freq & $\%$ & Freq & $\%$ \\
\hline 1 & Mohammedism & 10 & 62.50 & 5 & 31.25 & 1 & 6.25 & 16 & 100 \\
\hline 2.a & recruit an assassin & 10 & 62.50 & 6 & 37.50 & & & 16 & 100 \\
\hline b. & ayatollah[Khomeini] & 14 & 87.50 & 2 & 12.50 & & & 16 & 100 \\
\hline c. & standard Islamic practice. & & & 16 & 100 & & & 16 & 100 \\
\hline 3.a. & Islamic extremism & 8 & 50 & 8 & 50 & & & 16 & 100 \\
\hline b. & subversive radicalism & 13 & 81.25 & 3 & 18.75 & & & 16 & 100 \\
\hline c. & preemptive & 8 & 50 & 4 & 25 & 4 & 25 & 16 & 100 \\
\hline d. & fundamentalism & 12 & 75 & 4 & 25 & & & 16 & 100 \\
\hline e. & ruling Iranian hierarchy & 7 & 43.75 & 5 & 31.25 & 4 & 25 & 16 & 100 \\
\hline 4.a. & Islamist state & 3 & 18.75 & 13 & 81.25 & & & 16 & 100 \\
\hline b. & rogue state & 13 & 81.25 & 3 & 18.75 & & & 16 & 100 \\
\hline c. & Islamists & 12 & 75 & & & 4 & 25 & 16 & 100 \\
\hline 5. & would be better informed by... than... & 10 & 62.50 & 3 & 18.75 & 3 & 18.75 & 16 & 100 \\
\hline 6. & submit & 13 & 81.25 & 3 & 18.75 & & & 16 & 100 \\
\hline 7.a. & Muhammad's lifetime & 12 & 75 & 4 & 25 & & & 16 & 100 \\
\hline b. & veil & 2 & 12.50 & 14 & 87.50 & & & 16 & 100 \\
\hline c. & Muslim conquest & 3 & 18.75 & 13 & 81.25 & & & 16 & 100 \\
\hline 8.a. & Dar-ul-Islam & 14 & 87.50 & 2 & 12.50 & & & 16 & 100 \\
\hline b. & Jahilyyah & 15 & 93.75 & 1 & 6.25 & & & 16 & 100 \\
\hline 9 & God's guidance & 4 & 25 & 10 & 62.50 & 2 & 12.50 & 16 & 100 \\
\hline 10 & de-politicized & 8 & 50 & 4 & 25 & 4 & 25 & 16 & 100 \\
\hline Total & onses for 16 translators $(21 \times 16)=336$ & 191 & 56.85 & 123 & 36.60 & 22 & 6.55 & 336 & 100 \\
\hline
\end{tabular}

Note. Freq: frequency \%: percentage.

\section{Copyrights}

Copyright for this article is retained by the author(s), with first publication rights granted to the journal.

This is an open-access article distributed under the terms and conditions of the Creative Commons Attribution license (http://creativecommons.org/licenses/by/4.0/). 